Kaygl, 19(II)/2020: 427-444. Araştırma Makalesi | Research Article

Makale Geliş | Received: 24.06.2020

Makale Kabul | Accepted: 08.07.2020

Yayın Tarihi | Publication Date: 15.09.2020

DOI: 10.20981/kaygi.788616

Melike MOLACI

Dr. Öğr. Üyesi $\mid$ Assist. Prof. Dr. Necmettin Erbakan Üniversitesi, Sosyal ve Beșerî Bilimler Fakültesi, Felsefe Bölümü, Konya, TR Necmettin Erbakan University, Faculty of Social Sciences and Humanities, Department of Philosophy, Konya, TR ORCID: 0000-0002-8128-7706 melikemolaci@gmail.com

\title{
Stoa Felsefesinde Alegorik Yorum
}

Öz

Hermeneutik tarihinde alegori ile düzanlam arasında daima mevcut olan çekişme, kutsal metinlerin yorumlanmasına ilişkin tartışmalardan çok önce, felsefenin doğumunun müjdelendiği zamanlarda ortaya çıkar. Kadim filozofların şiire ve şairlere olan tutumunda; bilgi türleri ile varlık kategorilerinin oluşturulmasında; ahlaki, toplumsal ve siyasi kaygıların gerisinde hep var olan bu çekişme, geleneksel felsefeye özgü ikiliklerden sadece biridir. Düzanlamın bazen diyalektik bazen de apodeiktik akıl yürütmelerle olan ortaklığına karşı sanatın yanı başında duran alegorik yorum, felsefe tarihi boyunca pek çok filozofun düşüncelerini aktarırken kullandığı bir araç olmuştur. Bu çalışmada alegorik yoruma felsefelerinde özel bir yer ayıran, alegorilere ve metaforlara olan yaklaşımlarıyla hermenuetik tarihinde önemli bir yer işgal eden Stoacılar ele alınmaktadır. Hem ait oldukları geleneği hem de kendi öğretilerini temellendirmek üzere mitosları nesne edinen ve onlarda içerilen muammalara rasyonel açıklamalar getiren Stoacıların alegorileri nasıl yorumladıkları ise Stoa felsefesinde alegorik yorumun işlevi ve kapsamı bağlamında değerlendirilmektedir. Böylece yorum tarihinde özel bir yere sahip olan Stoacılığın bu konumu nasıl edinmiş olabileceğine ve ardıllarına bıraktığı mirasın ne ölçüde korunduğuna dair bir sonuca varmak olanaklı olacaktır.

Anahtar Kelimeler: Stoacılık, Hermeneutik, Mitos, Alegori, Alegorik Yorum.

\section{Allegorical Exegesis in Stoic Philosophy}

\begin{abstract}
In the history of hermeneutics, the controversy that has always existed between allegory and literal occurs when the birth of philosophy is heralded, long before the discussions about the exegesis of scriptures. This controversy, which always lies behind moral, social and political concerns, in the attitude of the ancient philosophers towards poetry and poets, in the creation of the categories of being and the kinds of knowledge, is just one of the philosophical dualities pertaining to traditional philosophy. The allegorical exegesis which takes art's side against the partnership of the literal with dialectical, and sometimes apodeictic reasoning has been a tool used by many philosophers to convey their thoughts throughout the history of philosophy. This study focuses on Stoics, who give particular importance to allegorical exegesis in their philosophy and occupy an important place in hermeneutics history with their approach to allegories and metaphors. Stoics take myths as objects to found both the tradition they belong to and their teachings and give rational explanations for the enigmas contained in them. The way Stoics interpret allegories is evaluated in the context and function of allegorical exegesis in Stoic philosophy. Thus, it will be possible to come to a conclusion about how Stoicism, which has a special place in the history of exegesis, could have acquired this position and to what extent the heritage left to its successors was preserved.
\end{abstract}

Keywords: Stoicism, Hermeneutics, Mythos, Allegory, Allegorical Exegesis. 


\section{Giriş}

Hermeneutik tarihinde alegori ile düzanlam arasında var olan gerilim ve çatallaşma, felsefe ile şiir, diyalektik ile retorik, kategori ile metafor arasındaki çetrefilli ilişkilerin bir uzantısıdır. Kadim metinlerin yazarları için hakikatin ifşası, okurlar için ise muammanın icrası olan alegori ve metafor, kaynağını antik şiirde bulsa ve bunlar hatiplerin söylevlerinin asli unsurları olsa da, bu metinler onlarda daha derin anlamlar gören filozoflar tarafindan yazarın asli niyetini gözler önüne seren gizli kapaklı (hyponoia) sözler (Platon 2017: 378d) ya da semboller (symbolon) (Arnim 1964: II.908; 911) olarak düşünülmüştür. Şairin sıradan okuyucuya değil de aslında küçük bir azınlığa hitap ederken kullandığı gizleme teknikleri, filozoflar için şiirin hakikatine ulaşmada çözülmesi gereken bulmacalara karşılık gelirler. Gerek metaforlar gerekse onlardan örülmüş alegoriler söz konusu olduğunda, bazı filozoflar için bu süsleme sanatları düz anlamın olanaksızlığını gösterir ve hakikatin ancak sanatla dile gelebilir olduğuna işaret eder. Dolayısıyla filozofun hakikati temellendirmek ve ifade edilmiş olanı yorumlamak için kullandığı metafor ve alegori, söylevlerdeki ve şiirlerdeki kullanımından ziyade felsefe metinlerindeki işleviyle önem arz eder.

Aristoteles'te anlamın başka bir ada aktarılması olarak tanımlanan metafor, bir sözcügün alışılmış anlamının dışında başka bir anlam ile açıklanması olarak düşünülür ve analojiyle birlikte anılır (Aristoteles 2012: 1457b). M. Ö. 1. yy’dan önce herhangi bir metinde geçmeyen 'alegori' ${ }^{1}$ sözcüğüyle ilgili olarak Cicero, "metaforların sürekli akışında tamamıyla farklı bir konuşma türünün ortaya çıktığını ve Yunanların buna alegori dediklerini" belirtir (Cicero 1939: 93). M. S. 1. yy’1n Stoac1 yorumcusu Herakleitos ise Homerosçu Problemler'de her tür sembolik ifadeyi alegori çerçevesinde düşünür ve alegorinin "başka bir şeyi söylemek" anlamına gelen etimolojik çözümlemesini yapar:

\footnotetext{
${ }^{1}$ Alegorinin ve metaforun antik metinlerde ortaya çıktığı bağlamlar ve anlamlar için ayrıca bkz.: (BoysStones 2003: 1-5).
} 
"Bu noktada alegoriye dair az da olsa teknik bir açiklama (tekhnoloēsa) yapmak kaçınılmaz gibi görünmektedir. Doğrunun (etymos) ifadesi şeklinde ortaya çıkan sözcügün kendisi, anlamını açığa çıkarmaktadır. Çünkü bir şeyi söylerken (agoreuōn) söylediğinden başka bir şeyi (alla) ifade etmeye çalışan mecaz (tropos), alegori ismini tam da buradan alır" (Heraclitus 2005: $5.1-2)$.

Antik felsefede başta Herakleitos ve Platon olmak üzere pek çok filozof, düşüncelerini dile getirirken alegori ve metafordan yararlanmıştır. Yorumlama söz konusu olduğunda ise bunun ilk örneklerine Anaksimandros, Pherekydes, Empedokles, Anaksagoras, Demokritos, Metrodoros ve Phythagoracçılarda rastlanır (Zeller 1870: 335). Tarihçi Favorinus'un aktardığına göre Homeros'un şiirlerinde ana konunun erdem ve adalet olduğunu ilk gösteren Anaksagoras'tır ve bu görüşü Metrodoros da savunmuştur (Laertios 2015: II.11). Yine Athena'nın isimlerinden biri olan "tritogeneia"yı bilgeliğin üç hali ile bir arada ilk kez düşünen Demokritos olmuştur (Diels\&Kranz 1974: 68 B2). Fakat yine de bu filozofların mitoslara olan yaklaşımı sistemli bir yorumlama değildir ve alegorik yorumun alışıldık kullanımına bir hayli uzaktır; onlar genellikle mitoslarda doğaya dair bir açıklama bulmak ve doğal olayları bunlardan hareketle anlamlandırmak isterler. Alegorileri ahlaki açıdan yorumlamaları beklenen Hippias, Prodikos ve Protogoras gibi Sofistler bile Platon'a göre etimolojiyle ilgilenmenin ötesine geçmemiş (Platon 2000: 384b) ve mitolojik yaratıkları yorumladıkları eserlerinde, bitmek tükenmez açıklamaları ile başarısızlığa mahkûm olmuşlardır. Nitekim Platon'a göre bu tarz kaba bilgilere (agroikō) yani geleneğe dayanarak yapılmaya çalışılan açıklamalar, çok zaman alır ve kişinin kendini tanımazken kendine yabancı olan şeyleri araştırması ise gülünçtür (Platon 2019: 229de).

Geleneğe olan eleştirisini İon'da da sürdüren Platon, yorumlama (hermēneuin) fillini, insanlar için bir tür bilmece olan, herhangi bir doğruluk değeri taşımayan ve düzanlamı aşan tanrı sözlerini yorumlayan şairleri tanımlarken kullanır ve şiiri tanrının tercümanı olan şairlerin esrimeleri (mania) olarak düşünür (Platon 1997: 535a). Eserlerinde şiire ve şairlere olan tutumu hayli tartışmalı olan Platon'un, düşüncelerini aktarırken alegorilere başvurduğu dikkate alınırsa, şairin değil ama filozofun aracı 
olarak alegoriyi önemsediği söylenebilir. Fakat bu durum alegorinin hatibi ile muhatabı arasındaki ilişkiyi silikleştirir ve Platon'un antik şiirlerin alegorik yorumuna dair düşüncelerindeki karanlığı aydınlatmaz. Bu hususta ifade edilebilecek yegâne şey, belki de ardılına nazaran Platon'un alegorik yoruma dair tutumunun daha 1lımlı olduğudur. ${ }^{2}$ Alegoriye oldukça mesafeli olan Aristoteles, fiilin isimleşmiş hali üzerine dilbilgisi kitabını andıran bir eser yazar (Peri Hermeneias) ve yorumlamayı büsbütün düzanlamıyla ele almış görünür (Yıldırım 2018: 172-3). Metafizik’te ise en uzak atalardan kalan ve bir efsane şeklinde daha sonraki kuşaklara aktarılmış olan geleneğin, yalnızca ilk tözleri tanrılarla bir tutan betimlemelerinin kabul edilebileceğini ifade eden Aristoteles, bunun dişında kalan bütün unsurların kitleleri ikna etmek ile yasalar ve kamu yararına hizmet etmek üzere uydurulduklarını düşünür (Aristoteles 1996: 1074b). Bu haliyle antik şiirde ve mitoslarda bulunan mecazları, fiziğin ve metafiziğin hizmetine sunmuş görünen Aristoteles, yorumu düzanlamıyla ele almadığında dahi, metaforların ötesine geçmez ve alegorik yorum pratiği ile olan mesafesini korur.

Yorum tarihinde ortaya çıkan belki de bu ilk yol ayrımı, Helenistik dönem ile birlikte önemli bir uğrağın alegori, sembolizm, dil ve retorik üzerine olan çalışmalarıyla belirli bir güzergâhta ilerler. Fizik, mantık ve etiğe dair teorilerini desteklemek ve onları anlaş1lır kılmak üzere antik mirasa dair şerhleriyle karşılaştırmalı mitolojinin ve alegorik yorumun belki de en kapsamlı örneklerini sergilemiş olan Stoacılar, hermeneutik tarihinde önemli bir "kırılma anı"nı başlatırlar. ${ }^{3}$ Zira Stoacılar alegori hususunda öncelleriyle benzer bir inancı tam olarak paylaşmazlar. Antik filozofların iki uçlu bir alet olarak düşündükleri alegori, bir yandan antik şairleri bilgelikleri nedeniyle

\footnotetext{
2 Platon'un alegorik yoruma dair tutumunun daha 1lımlı olduğu iddiası nisbi bir iddiadır. Aristoteles ile kıyaslandığında Platon'un alegorileri, mitosları ve analojileri daha sık kullandığı görülür. Bununla birlikte başta Devlet olmak üzere muhtelif eserlerinde Platon, şiiri, felsefi bilgiden aşağ 1 türde bir bilgi sunduğu gerekçesiyle eleştirir ve şairleri dini, ahlaki ve siyasi gerekçelerle ideal devletinde barındırmak istemez (Platon 2017: 377c-394e; 599a-605c).

3 Stoacı alegorik yorumun bir "kırılma anı" olarak düşünülmesi, hermeneutik tarihinde alegorinin mucidinin Stoacılar değil, Stoacı pratiğin Kinik kökenleri olduğunu belirtmek içindir. Özellikle mitleri doğal olayların açıklanması yerine ahlaki açıdan yorumlayan Kinik okul, Stoacılar için pek çok konuda olduğu gibi yorumlama bakımından da örnek oluşturur. Bununla birlikte Kinikler'in fiziğe ve mantığa olan mesafeleri, Stoacı alegorinin Kinik kökenlerinden ıraksamasına ve kapsamının genişlemesine neden olmuş görünür.
} 
övmeyi öte yandan hakikati doğrudan ifade etmemeleri nedeniyle onları yermeyi sağlar. Oysa Stoacılar için Homeros ve Hesiodos'un şiirleri bilgeliğin tezahürüdür ve hatta “yalnızca şairler bilgedir” (Strabo 1917: I.2.3). Şiirlerde gizlenmiş olan her türlü hakikat, reddedilmeyi değil, açımlanmayı bekler. Dolayısıyla alegorik yorum, kadim yazarlara yöneltilen eleştirileri ortadan kaldırmayı ve hatta gizlenmiş olan hakikati rasyonelleştirmeyi sağlar. Mitoslara anlamlı bir yorum getirmek ve adların kökenini araştırmak gibi zahmetli bir işe ilk girişenin Kıbrıslı Zenon olduğu (Cicero 2012: III.63) dikkate alınırsa, alegorik yorumda Stoacıların hatırı sayılır bir etkisinin olduğu yadsinamaz.

Bununla birlikte erken dönem Stoac1lıkta alegorinin, metaforun ya da alegorik yorumun sistemli bir şekilde kullanıldığına ilişkin tam bir metne ya da bütünlüklü bir aktarıma rastlanmaz. Cicero'nun Zenon, Kleanthes ve Khryippos'un alegorik yoruma dair görüşlerini aktardığı Tanrıların Doğası'nın yanı sıra, bu konudaki en erken tarihli tam metin M. S. 1. yy'dan kalma Herakleitos'a ait Homerosçu Problemler'dir. Yine Seneca'nın çağdaşı Kornoutos'un Epidrome adlı eseri de alegorik yoruma dair önemli ipuçları sunan belki de en önemli birincil kaynaktır. Alegorik yoruma dair bir savunmayla başlayan Homerosçu Problemler, şairlere olan yaklaşımı nedeniyle Platon ve takipçilerinin eleştirisiyle sürer. Kitabın konusunu oluşturan İlyada ve Odysseia yorumu, Homeros'un dindarlığını ve bilgeliğini temellendirmeye, onda gizlenen hakikatin "saflığını" göstermeye yarar (Heraclitus 2005). Epidrome'da kadim şairlere olan tutumu ikircimli olan (Cornutus 2018: 27.50; 35.75-6) Kornoutos, Herakleitos gibi Homeros'un "saf" bilgeliğini kanıtlanmakla ilgilenmez. Eser boyunca tanrıların ve kutsal karakterlerin adlarına dair pek çok etimolojik çözümleme seçeneği sunulur ve muhtemelen bu konuda Stoacılığa yöneltilmiş eleştirilerin bertaraf edilmesi amaçlanır. Pedagojik ve apolejetik amaçlarla yazılmış görünen bu eserde, antik düşünürlerin sıradan insanlar olmadıkları; evrenin doğasını anlama yeteneğine sahip bu insanların düşüncelerini aktarırken sembolleri (symbolon) ve muammaları (ainigma) kullanmaya meyilli oldukları ifade edilir (Cornutus 2018: 76.1-5). 
Bu haliyle alegoriye ve ona ilişkin yorum pratiğine özel bir ilgi duyan Stoacıların, başta Ískenderiye Okulu düşünürleri olmak üzere Kitab-1 Mukaddes'in alegorik yorumcularına kılavuzluk etmiş olmaları nispeten anlaşılır bir durumdur. Origenes'in başı çektiği ve uzun bir süre egemen olan alegorik yorum geleneği, düzanlamı mahkûm edip hakikatin alegoriler aracılığıyla vahyedildiğini ortaya koyduğu sırada, Stoacı öncülleri ve birikimi kullanmaktan geri durmamıştır. Origenes alegorik yorumda etimolojik çözümleme tekniklerini Stoacılardan devraldığını açıkça belirtirken (Origenis 1876: I.24), Eusebios Origenes'in alegorik yorumu Stoac1 Kornoutos ve Khairemon'un kitaplarından öğrendiğini ifade eder (Eusebius 1942: VI.19.8). Kuşkusuz Origenes ve diğer alegori yorumcularının yegâne kaynağı Stoacı metinler değildir. Orta ve YeniPlatoncu metinler ve Platon'un Yeni Ahit ile bağdaştırılabilecek ontolojisi, Hristiyan hermeneutiğinin Stoacı alegorik yorumdan amaçları ve sonuçları bakımından farklılaşmasına neden olmuş görünür. Fakat amaçlar ve sonuçlar ne kadar farklı olursa olsun, alegorik yorumun uzun süren egemenliğinin miladının Stoacılık olduğunu iddia etmek yine de mümkündür.

Stoacılığın hermeneutik tarihinde ve özellikle alegorik yorum geleneğinde önemli bir yer işgal etmesi ve Stoacıların antik metinlere olan yaklaşımı, içerdiği bütün özgünlüklerle birlikte ilgi çekici bir araştırma konusudur. Stoacıların alegoriyi felsefelerinde nereye konumlandırdıkları, alegorik yorum ile neyi amaçladıkları, alegorileri ne bakımdan yorumladıkları ve felsefelerini temellendirirken alegorilerden ne ölçüde yararlandıkları, Stoacı alegorik yorumun işlevine, anlamına ve kapsamına ilişkin önemli izleklerdir.

\section{Stoacı Alegorinin İşlevi}

Alegorik yorumun Stoa felsefesinde işgal ettiği yer, pek çok yazarın ilgisini çekmiş ve bu konuda önemli bir literatür oluşmuştur. ${ }^{4} \mathrm{Bu}$ literatürde Stoacıların niçin

\footnotetext{
${ }^{4}$ Zeller (1870), Reinhardt (1910), Wehrli (1928) ve Pohlenz (1948) gibi Alman yazarların nispeten erken tarihli çalışmalarının yanı sıra Tate (1929), De Lacy (1948), Buffıère (1956), Pfeiffer (1960), Thompson (1973), Le Boulluec (1975), Pépin (1976), Hays (1983), Steinmetz (1986), Whitman (1987), Most (1989), Boys-Stones (2003), Van Sijl (2010) ve Ramelli (2011) gibi yazarlar da Stoacı alegorinin mahiyeti ve
} 
alegorilere ilgi duydukları ve alegoriyi ne amaçla kullandıklarına dair çeşitlenen iddiaların yanı sıra, alegorilerin çözüm sunduğu konulara ilişkin pek çok yoruma da rastlanmaktadır. İşlev ve kapsama ilişkin bu çelişkili yorumlar yumağında ilkin, ilk izleğin yani Stoacı alegorinin işlevinin ne olduğu sorusu cevaplanmalıdır. Bu soruya verilmiş yanıtları dört başlık altında toplamak mümkündür. Zeller'in öncüsü olduğu ilk yanıta göre, Stoacılar için alegorik yorum, "Yunan İncili" olan geleneksel şiirin, felsefeyle uzlaşamayacağına dair iddiaları ortadan kaldırmaya ve felsefenin yaygın inançlara ve değerlere olan taarruzuna karşı, geleneği yine felsefe aracılığıyla kurtarmaya yarar (Zeller 1870: 336-348). Bu yanıt, alegorinin geçerli bir yöntem olduğu ve bu yöntemin Stoa felsefesindeki kullanımının yararı ortaya konulduğunda hem geleneğin hem de Stoacı düşüncenin meşruiyetinin sağlanacağı iddiasına dayanır. Zeller'in iddiasını yineleyen Van Sijl, bu ikili kurtarma planının aynı zamanda Stoacı bilgi teori açısından zorunlu olduğunu da belirtir. Van Sijl'e göre özellikle erken dönem Stoacıların, etimoloji incelemeleriyle eş değer olan "atomik yorumları", bütün insanlarda ortak olan genel kavramların mahiyetini aydınlatmaya yarar ve Stoacılar bu sayede hem kendi felsefelerine hem de ait oldukları geleneğe bir geçerlilik kazandırabilirler (Van Sij1 2010: 250-252). Bu ikili kurtarma planına karşı geliştirilmiş ikinci seçenekte ise Tate ve Pfeiffer alegorik yorumun ikili işlevini reddederler ve alegorilerin apolojetik bir işlevi olduğu konusunda 1srar ederler. Buna göre Stoacılar alegorik yorum aracılığıyla Homeros ve Hesiodos'u aklamayı değil, kendi felsefelerini gelenekle bağdaştıran bir savunma yapmayı amaçlarlar. Dahası Tate'ye göre alegorik yorum pratiğinin Stoa felsefesinde özsel bir yeri bulunmaz; antik şiir Stoacı dogmayı kuvvetlendirdiği ölçüde işe yarayan bir araca indirgenir (Tate 1930: 3). Alegoriler Stoa felsefesinin başta logos doktrini olmak üzere pek çok kuramını temellendirmeye yarayan ve onun güvenilirliğini destekleyen argümanlar sunarlar (Pfeiffer 1968: 237-8).

İster tek taraflı isterse çifte olsun alegorinin meşrulaştırıcı işlevine ilişkin iddialardan farklı bir seçenek sunan üçüncü ve dördüncü yanıtlar ise Stoacılar için

kullanımına dair ufuk açıcı düşünceler ortaya koymuşlardır. Stoacı alegorik yoruma ilişkin literatür için ayrica bkz. (Most 1989: 2018; 2059-2065). 
edebiyatın ve sanatın özerkliğini tartışmaya açarlar. Steinmetz alegorinin Stoa felsefesinde ve özellikle erken dönem düşüncede önemsiz bir detay olduğunu; Zenon, Kleanthes ve Seleukeialı Diogenes'in alegorik yorumla değil, etimoloji ile ilgilendiklerini iddia eder. Steinmetz’e göre erken dönem Stoacılıkta alegorik yorum, felsefeyle değil, retorik ve edebiyatla ilgilidir (Steinmetz'den aktaran Most 1989: 20234). Edebiyatın özerkliğinin temellendirilmesine ilişkin bir çaba olarak okunması mümkün olan bu yorumda, Stoacıların antik şiiri, şiir olarak ele aldıkları ve alegorik malzemenin felsefi değil, edebi olduğu vurgulanır. Alegorik yorumun Stoa fiziğinin ve teolojisinin asli bir parçası olduğunu iddia eden Ramelli ise bu iddiasını, Stoa teolojisinin araştırma konularından hareketle temellendirir. Buna göre Kleanthes'in ortodoks bölümlemeden ayrılan altılı felsefe ayrımında teoloji ve retoriği ayrı birer disiplin olarak düşünmesi ve Khrysippos'un fiziğin ereği olarak konumlandırdığı teolojinin konuları arasında mitosları anması, alegorik yorumun felsefeden ayrı düşünülemeyeceğini ve hatta onun felsefe araştırmalarının önemli bir bölümünü oluşturduğunu gösterir (Ramelli 2011: 336-41).

Stoacı alegorik yorumun işlevine dair söz konusu bu yorumlar çeşitliliği, ilk bakışta sorunun karar verilemez olduğunu düşündürtebilir. Ancak yorumlarda vurgulanan hususlar dikkatle izlendiğinde ve Stoacı metinlere yakından bakıldığında işlev sorusuna bir yanıt vermek olanaklı hale gelir. Şöyle ki dört başlıkta özetlenen farklı iddialar, erken dönem Stoacılığa odaklanmış görünmektedirler. Özellikle Stoacı pratiği bir savunma olarak konumlandıran ikinci iddianın Roma dönemi Stoacılığı ile bağdaştırılması mümkün değildir; zira bu dönemde Stoa felsefesinin gelenekle kendini temellendirmeye ihtiyacı bulunmaz, aksine gelenek bu dönemde neredeyse Stoa felsefesi tarafından belirlenir. ${ }^{5}$ Fakat alegorinin Stoa felsefenin bütün dönemleri için önemli doktrinleri temellendiren bir araç olduğu iddiası yadsınamaz. Erken dönem düşüncede logos, kader ve büyük tutuşma gibi fiziksel doktrinleri anlaşılır kılan Zeus,

\footnotetext{
${ }^{5}$ Geleneksel Roma dininin Stoacı düşünceler içerdiği iddiası, tanrıların doğası hususunda sessiz kalmayı seçen Cicero'nun tavrında oldukça aşikârdır. Stoacı teolojiyi alenen eleştirdiği Kehanet Üzerine'ye nazaran daha kamusal bir konuşmayı kayda geçiren Tanrıların Doğası'nda Akademiacı Cicero'nun Stoacı Balbus'un düşüncelerini kendine yakın bulması bunun bariz bir örneğidir (Cicero 2012: III.95).
} 
Athena, Hephaistos, Herakles ve Medeia gibi mitolojik figürler (Arnim 1964: I.509514; II.908; 1021-1027; 1076-1100), orta ve geç dönemde Akhilleus ve Odysseus gibi kahramanlari le Sokrates, Diogenes, Cato ve Hannibal gibi kişiliklerin de dâhil olduğu genişletilmiş yeni panteondo, başta etik olmak üzere pek çok teoriyi temellendirmeye devam ederler (Italicus 1934a; b; Epictetus 1998 I.6; II.16; 18; 1928: III.22; 24; IV.10; Cicero 2014: III.25; Seneca 2017: II.1). Bu dönemde örnek alınan modellerin yalnızca mitos kahramanları olmamaları bu iddianın geçersizliğini bir kez daha teyit eder. Mitosların dogmayı pekiştiren araçlar olduğu iddiası ise "yalnızca şairlerin bilge olduğu" ifadesi tarafından doğrulanır gözükse de, bu ifade aynı zamanda "yalnızca bilgelerin şair olduğu" anlamına gelir ve şiir ile felsefe arasında varsayılan ayrımı ortadan kaldırır. Bu haliyle bir meşrulaştırma çabasından bahsetmek olanaklıysa, bunun yalnızca dogmanın savunusu değil, aynı zamanda geleneğin de savunusunu içeren iki taraflı bir meşrulaştırma olarak düşünülmesi gerekir.

Temellendirmelerini erken dönem metinlerden hareketle ortaya koyan ve özerklik problemini tartışmaya açan üçüncü ve dördüncü yanıtları ise bir arada düşünmek mümkündür. Kuşkusuz Stoacılar için etimoloji çalışmaları alegorik yorumun önemli bir bölümünü oluşturur, bununla birlikte Stoacıların etimolojiye olan ilgileri mitosların yorumlanmasıyla sınırlı değildir. Etimoloji doğal teolojiye ve fiziğe ait kavramların çözümlenmesinde daima işlerlik gösterir. Stoacılar tanrıların çeşitli güçlerine dair etimolojik analizleri sürdürdükleri kadar (Heraclitus 2005; Cicero 2012: II.60-70; Laertios 2015: VII.147; Cornutus 2018) yükümlülük, kader ve sorumluluk gibi fizik ve etiğe ait kavramların da kökenlerini aramaktan geri durmazlar (Eusebios, 1871: VI.8.8; Cicero, 1923: 1.125; Arnim, 1964: II.917- 920). Hatta Cicero ve Galenos'un yakınarak ifade ettikleri üzere Stoacı etimoloji ve neolojizm, öncel düşüncelerin Stoacılar tarafından yeniymiş gibi sunulduğu intibası bırakır (Cicero 1931: IV.22; 1967: I.35-43; Arnim 1964: II.322). Bu haliyle etimolojik analiz nedeniyle alegorik yorumu retoriğe yerleştiren üçüncü iddia ya geçersiz sayılmalı ya da Stoa felsefesi bütün olarak edebiyattan ibaret olarak düşünülmelidir. İkinci seçenek olanaksız olduğuna göre alegorik yorumun işlevinin felsefi olduğu açıktır. Ayrıca Ramelli’nin 
temellendirmesinde dikkat çeken en önemli husus Stoacıların özerkliği bir sorun olarak düşünmemiş olmalarıdır; retoriğin ya da edebiyatın felsefenin bölümlerinden biri olması en azından erken dönem Stoacılar için sorun teşkil etmez. Platon ve Aristoteles'e olan muhalefetleriyle erken dönem Stoacılar, retorik ya da sofistiğin de en az diyalektik ya da apodeiktik akıl yürütmeler kadar önemli olduğunu düşünürler (Laertios 2015: VII.41-43). Ancak psikoloji görüşleri bakımından ortodoks görüşten ayrılan orta dönem düşünürü Poseidonius ve pratik felsefeyi yücelten geç dönem Stoacılar ile birlikte retoriğin ve mitosların kısmen felsefeden ayrı düşünülmeleri söz konusu olur (Galen 2005: IV.7; Seneca 1992: 88.5; 18; Epictetus 1998: I.26.3). Ne var ki bu dönemde Seneca'da açıkça görülen bu olumsuz tutum, mitoslara ve alegoriye eserlerinde özel bir yer veren ve Stoacı alegorik yorumun en uç örneklerini sergileyen Herakleitos, Kornoutos, Dio Khrysostomos, Silius Italicus, Persius ve Lukianos tarafindan paylaşılmaz. Antik şiir ve alegori artık felsefe olarak görülmese bile, felsefi bir araç olarak varlığını sürdürür. Bu dönemde edebi metinlerin felsefeden sürülmesi alegoriyi önemsiz kılmaz; alegorik yorum yalnızca kapsamı bakımından ahlak ile sınırlandırılır.

Alegorik yorumun Stoacılar açısından çifte meşruiyet sağlaması ile şiirin felsefenin bir bölümünü oluşturması ise uzlaştırılabilir iki iddiadır. Alegorilerin, hem geleneği hem de Stoa felsefesini kurtarma girişimleri olarak düşünülmeleri, doksografiler aracılığıyla doğrulanabilir durumdadır: "[Tanrılar Üzerine’nin] ikinci kitabında Khrysippos, tıpkı Kleanthes gibi Orpheus ve Musaios'a, Homeros ve Hesiodos'a, Euripides ve diğer şairlere atfedilen şeyleri Stoacı doktrinle uyumlu hale getirmeye çalışır” (Arnim 1964: I.539) ve bu konuda pek çok açıdan ustaca olan ikna edici açıklamalar yapar (Galen 2005: II.8.26). Stoa felsefesinin meşruiyetine dair bu aktarımların yanı sıra şairlerin itibarını da güvence altına almak adına Zenon’un şairlere olan 1lımlı tutumundan bahseden tanıklıklar da mevcuttur. Dio Khrysostomos'a göre bazen sanıya bazen de hakikate göre yazan Homeros'u hiçbir bakımdan suçlamayan Zenon, onda herhangi bir çelişki görmez ve tutarsız olduğu iddia edilen hususları, tüm ayrıntılarıyla açıklığa kavuşturur (Arnim 1964: I.274). Bu haliyle kendi öğretilerinin yanı sıra geleneği de hakikat kaynağı olarak gören Stoacılar, aslında şairleri "proto- 
Stoac1“ya da kendilerini “post-şair” olarak düşünürler. Nitekim Cicero’nun Epikourosçu karakteri Velleius'un alaycı bir biçimde belirttiği üzere Khrysippos'un amacı, bu konuda varsayımda bulunmamış olsalar bile en eski şairlerin de Stoacı olduklarını göstermektir (Cicero 2012: I.41). O halde birinci iddianın işaret ettiği üzere alegorinin hem Stoa felsefesini hem de geleneği meşru kılan bir araç olarak kullanılmış olması, aslında onun bir yöntemden fazlası olması anlamına gelir. Özellikle erken dönem Stoacıların mitoslara dair şerhleri ve şairlere yönelik tutumları göz önünde bulundurulduğunda, mitosların ve alegorinin felsefi araştırmanın önemli bir bölümü olarak düşünülmüş olduğunun kabul edilmesi gerekir. Bu ise Stoa felsefesinde alegoriyi önemli bir araştırma alanı haline getirmesinin yanı sıra, onun işlevi ile kapsamını bir arada düşünmeyi olanaklı kılar.

\section{Stoacı Alegorinin Kapsamı}

Stoa felsefesinde alegorik yorumun felsefenin bir bölümünü oluşturduğu kabul edildiğinde, onun kapsamına dair sorun da açıklığa kavuşur. Stoacılar için şiir, neredeyse mantıkla eş anlamlı olarak düşünülen ve sağlam uslamlamalar kurmak için zorunlu olan diyalektiğin konularından biridir (Laertios 2015: VII.44). Yine Aetios'a göre Stoa teolojisinin konularından biri olan şiir, şairlerin yaratımı (peplasmenon) olup evrenin doğası hakkındaki kadim fikirlerin de kaynağıdır (Arnim. 1964: II.1009). Bu haliyle alegoriler mantık, fizik ve etik kuramlarını anlamayı sağlayan felsefi araçlar olarak düşünülürler.

Epistemolojik açıdan mitoslar Stoacı “ön-kavrayış (prolēpsis)” kuramı ile yakından ilişkilidirler. Stoa epistemolojisinde kimi zaman doğruluk ölçütü olarak düşünülen ön-kavrayış, tümel şeylerin (katholou) doğal bir kavrayışıdır (Laertius 1931: VII.54). Aetius'un aktardığı üzere benzer izlenimlerin (phantasia) hatırlanmasıyla meydana gelen deneyim (empeiria) ve bunun sonucu olan kavramdan (ennoiai) farklı olan ön-kavrayış, doğaldır; dikkatle, öğrenmeyle ya da bilinçli bir yönelimle ilgili değildir (Arnim 1964: II.83). Bütün insanların sahip olduğu ön-kavrayışlar, birbiriyle çelişmezler; fakat tanımlamada ve kanıtlamada yani uygulamadaki kullanımlarında 
kişiyi yanlışa sürüklerler (Epictetus 1928: IV.1.42). Bilginin edinilmesinde izlenimle benzer bir işleve sahip olan fakat ona ihtiyaç duymayan bu "doğal kavramların (physikiaennoiai)" mahiyeti ise teolojik ve etik araştırmalarda belirginleşir. Cicero Tanrıların Doğası 'nda tanrının varlığına ilişkin ilk kanıtlamasını dinin yahut inanmanın evrensel bir fenomen olduğu öncülüne dayandırır (Cicero 2012: II.13). Sonradan "argumentum e consensuomnium" olarak adlandırılacak olan bu kanıtlama biçimine göre insanlar, doğasının mahiyeti konusunda anlaşmazlık gösterseler de tanrının varlığına inanırlar. Bütün insanların zihninde bulunan yüce varlık tasarımının kökeni ise insanların tanrıya ilişkin ön-kavrayışlarıdır ve bu ortak kavrayışta insan, tanrının canlı, bozulmaz, kutsal ve lütufkâr bir varlık olduğunun farkına varır (Plutarch 1976: 1051f). Ön-kavrayışların bütün insanlarda ortak olan doğal kavramlar olması, mitosların “insanlığın öyküsü”nü anlattıklarının kanıtı olarak düşünülür. Stoacılar mitoslarda yer alan tanrı tasarımlarına ilişkin şerhleri ve tanrıların adlarını konu olan etimolojik analizleriyle bütün insanlarda ortak olan bazı önsel kavramları tanımlarlar. Bilgi için zorunlu olan tanımın başlangıç noktası olan ön-kavrayışlar (Empiricus 1933: III.169-73) alegorik yorumla anlaşılır hale gelirler. Stoa epistemolojisinde genel kavramların doğrudan duyumla kavranmasının yanında analoji, benzetme, oranlama, bir araya getirme ve karşıtlık yolu da kullanılır (Laertios 2015: VII.52-53). Bu yollardan analoji ve oranlama mitosların alegorik yorum aracılığıyla kanıtlanmasını sağlarken, kanıtlama akılla kavrandığında bilgi ortaya çıkar.

Alegorik yorumun ilk basamağını oluşturan etimolojik analizler ise Stoacıların dil felsefesi olarak adlandırılabilecek alandaki çalışmalarının temelini oluşturur. Doğalcı dil teorisini savunan Stoacılar için adlar ve sesler ile imlediği nesneler arasında bir karşılıklılık bulunur. Kuşkusuz bütün varlıklar da ortak olan ve onları birbirine bağlayan logos sayesinde, etimolojik araştırmalar ve alegorik yorum meşru etkinlikler olarak düşünülür. Frede'nin de belirttiği üzere Stoacılar, konuşmanın ve dilin rasyonelliği yansıttığını düşünürler (Frede 1978: 61). Bu nedenle etimoloji hem tanrıların doğasını hem de insani düşünmeyi anlamayı sağlar, bunlar anlaşıldığında ise mantık, etik ve fizik araştırmaları olanaklı hale gelir. 
Stoa felsefesinde alegori, epistemolojinin yanı sıra kozmoloji ve teoloji araştırmalarında da önemli bir araç olarak işlerlik gösterir; başta Zenon ve Khrysippos olmak üzere erken dönem filozofları, mitoslara dair kitaplar yazıp bu kitaplarda doğal güçler ile mitolojik varlıklar arasında yakınlık kurarlar. Stoacılar için alegorik yorum teoloji araştırmasının büyük bir bölümünü oluşturur:

"Bir bütün olarak teoloji erken dönem düşünceleri ve mitosları inceler, çünkü kadim düşünürler gerçeklikle ilgili sahip oldukları fiziki kavramları muammalarla (ainigmata) ifade etmişlerdir ve daima kendi öğretilerine mitik unsurları eklemişlerdir. Bugün bütün bu muammaları kesin olarak çözmek kolay değildir, ancak bazen birbiriyle tutarlı bazen de çelişik olan bu mitoslar yığını önümüze konulsa, hakikatin ne olduğuna dair varsayımda bulunmak daha kolay olabilirdi" (Strabo 1928: X.3.23).

Ayrıca erken dönem düşünürlerin yorum malzemeleri Homeros ve Hesiodos'un şiiriyle de sınırlı kalmaz; görsel sanatlar, tragedyalar, komedyalar ve geleneksel hikâyeler de yorumlamanın bir bölümünü oluştururlar (Van Sij12010: 98; 106). Fizik söz konusu olduğunda tanrıların adları ve işleri doğal güçlerle eşleştirilir, yine tanrılar, yarı-tanrılar ve mitolojik kahramanlar ahlaki açıdan izlenmesi gereken örnekler olarak düşünülürler (Cicero 2012: II.60-70; Arnim 1964: II.909; 914; 925; 937). Bununla birlikte Stoacılar için mitoslarda geçen tanrı betimlemeleri, salt fiziksel unsurlar ya da doğal güçler olarak görülmez, onlar her şeyi kuşatan ve bütün varlıklarda ortak olan logosun tezahürleri olarak anlaşılırlar. Roma Stoacılığında ise mitoslar doğal güçlere kaynaklık etme özelliklerini yavaş yavaş yitirirler; bu dönemde pratik felsefeye yahut ahlaka verilen öncelikle birlikte, mitolojik ve trajik kahramanların işleri, insanın ders alması ya da örnek olarak benimsenmesi gereken etkinlikler olarak düşünülür; geleneksel ve tarihsel kahramanlar büyük ölçüde idealleştirilir (Epictetus 1928: 51.3; Cicero 2014: III.25). Bu haliyle Stoa felsefesinde şiir ve onda içerilen alegoriler, ortodoks bölümleme açısından mantığın konularına dâhil edilmiş olsalar da, şiirin yorumlanmasının fizik ve etikte de işlerlik gösterdiği; diğer bir deyişle alegorinin felsefenin bütün alanlarında etkili bir araç olarak düşünüldüğü görülür. 


\section{Sonuç}

Stoacılar için özel ve öncelikli bir araştırma alanı olarak düşünülen geleneksel şiir, içerdiği semboller, metaforlar ve alegorilerle hakikatin kaynağı iken, muammalarla konuşan şairler de bilgelikleri ve hakikate olan tutumları nedeniyle örnek alınması gereken kişilerdir. $\mathrm{Bu}$ haliyle şaire karşı filozofu, retoriğe karşı da felsefeyi yüceltmeyen Stoacılar, bu alanlar arasında asli bir farkın bulunduğunu düşünmezler. Hatta yüzyıllarca hüküm süren teorik felsefe geleneğinin şairi sürgüne yollamasının aksine, şairlere bilgelik payesi veren Stoa felsefesi, şairin sözünü yorumlanması ve açımlanması gereken asli bir kaynak olarak görür. Stoa felsefesinin bütün alanlarında işlerlik gösteren alegorik yorum, evreni, insanı ve tanrıları anlamayı sağlarken buradan türetilen bütün bilgiler, erken dönem Stoacı kuramların oluşturulmasında kullanılır. Alegorik yorum sayesinde fiziğin, etiğin ve mantığın müstakil teorileri ilişkili hale gelirken hem öğretinin bütünlüğü hem de geleneğin meşruiyeti bu yolla temellendirilmiş olur. Erken dönem Stoacılık açısından hem felsefi bir proje hem de çifte meşruiyet kaynağı olan alegorik yorum, okulun ileri dönemlerinde toplumsal ve politik alanlarda da belirleyici olan bir etkinliğe dönüşür. Geleneksel teolojiyi yaygın inançlarla uzlaştıran, biyografilerden etik idealler ile ahlak reçeteleri çıkaran ve kehanet teorilerinin de yardımıyla meşru ritüellere kaynaklık eden Stoacı alegorik yorum, Roma toplumunun sosyal ve politik dokusuna önemli ölçüde etkide bulunur.

Yeni-Platonculuğun hâkimiyet kazanıp Stoacılığın gözden düştüğü sırada ise Stoacı bedenselciliğe yüz çeviren Hristiyan yorumcular, özünde kuramsal bir tutarlılık bulunan, konu edindiği mitoslarla uzlaşabilir olan ve felsefi amaçlarla kullanılan Stoacı alegorik yorumun amacını ve anlamını göz ardı ederler. Fakat kendilerine yabancı ve bir o kadar da çelişik olan bir sistemi temellendirmeye yarayan bu aracı, çekinmeden kendi teorilerini temellendirmek üzere kullanırlar. Hristiyan dogmasına taban tabana zit olan Stoa fiziğinin ve büyük ölçüde bu fiziği konu alan alegorilerin -apolojetik amaçlarla da olsa- Hristiyanlarca benimsenmesi, alegorik yorum tarihindeki tutarsızlığa, süreksizliğe ve kırılmaya dair önemli ipuçları sunar. Dahası alegorik yorum malzemesinin dogma ile 
uzlaştırılamaz olan yönleri, ontoloji ya da metafiziğe ait öğretileri temellendirmede kullanılan öncüllerin tutarsız olabileceğine dair oldukça çarpıcı bir örnek teşkil eder. Ayrıntılarına burada değinmenin mümkün olmadığı bu tuhaf durum için ifade edilebilecek tek şey, varlığa ilişkin teoriler ile bunları temellendirmeye olanak sağlayan yorumlama etkinliğinin, temelleri ve amaçları bakımından bu denli uzlaştırılamaz olmalarıdır. Bu husus ise hermenuetik tarihi ile ontoloji tarihinin her zaman yan yana gitmediğini göstermesi bakımından da ayrıca önemlidir. 


\section{KAYNAKÇA}

ARISTOTELES (1996). Metafizik, 2. Basım, çev. Ahmet Arslan, İstanbul: Sosyal Yayınları.

ARISTOTELES (2012). Poietika, çev. Nazile Kalaycı, Ankara: Pharmakon Yayınevi.

ARNIM, Hans von (1964). Stoicorum Veterum Fragmenta Vol. I-IV, Stuttgart: Teubner.

BOYS-STONES, George. R. (2003a). "Introduction". Metaphor, Allegory, and the Classical Tradition: Ancient Thought and Modern Revisions, ed. G. R. Boys-Stones, pp.1-5, Oxford: Oxford University Press.

CICERO, Marcus Tullius (1923). On Divination, trans. by W. A. Falconer, Cambridge, Harvard University Press.

CICERO, Marcus Tullius (1931), On Ends, trans. by H. Rackham, Cambrdige: Harvard University Press.

CICERO, Marcus Tullius (1939). Brutus-Orator, trans. by G. L. Hendrickson \& H. M. Hubbell, Cambridge: Harvard University Press.

CICERO, Marcus Tullius (1967). Academica, trans. by H. Rackham, Cambridge, Harvard University Press.

CICERO, Marcus, Tullius (2012). Tanrıların Doğası, çev. Çiğdem Menzilcioğlu, İstanbul: Kabalcı Yayınevi.

CICERO, Marcus, Tullius (2014). Yükümlülükler Üzerine, çev. C. Cengiz Çevik, İstanbul: Türkiye İş Bankası Kültür Yayınları.

CORNUTUS, L. Annaeus (2018). Greek Theology, Fragments, and Testimonia, trans. \& ed. G. Boys-Stones, Atlanta: SBL Press.

DIELS, H. \& KRANZ, W. (1974). Die Fragmente der Vorsokratiker. Three Vols. Berlin: Weidmann.

EMPIRICUS, Sextus (1933). Outlines of Pyrrhonism, trans. by R.G. Bury, Cambridge: Harvard University Press.

EUSEBIOS (1871). Eusebii Caesariensis Opera Vol I Praeparationis Evangelicae Libri I-X, ed. Wilhelm Dindorf, Leipzig: B. G. Teubneri.

EUSEBIUS (1942). The Ecclesiastical History Volume II. Books 6-10 trans. by J. E. L. Oulton, Cambridge: Harvard University Press.

EPICTETUS (1928). Discourses Books 3-4-Fragments the Encheiridion, trans. by W.A. Oldfather, Cambridge, Harvard University Press.

EPICTETUS (1998). Discourses Books 1-2, trans. by W.A. Oldfather, Cambridge, Harvard University Press. 
FREDE, Michael (1978). "Principles of Stoic Grammar", The Stoics, ed. J. Rist, pp. 27-75, London: University of California.

GALEN (2005). On the Doctrines of Plato and Hippocrates, trans. \& ed. Philip De Lacy, Berlin: Akademie Verlag.

HERACLITUS (2005). Heraclitus, Homeric Problems, trans. \& ed. Donald A. Russell ve David Konstan, Atlanta: SBL Press.

ITALICUS, Silius (1934a), Punica, Volume I: Books 1-8, trans. by J. D. Duff. Cambridge: Harvard University Press.

ITALICUS, Silius (1934b), Punica, Volume I: Books 9-17, trans. by J. D. Duff. Cambridge: Harvard University Press.

LAERTİOS, Diogenes (2015). Ünlü Filozofların Yaşamları ve Öğretileri, çev. Candan Şentuna, İstanbul: Yapı Kredi Yayınları.

LAERTIUS, Diogenes (1931). Lives of Eminent Philosophers Books 6-10, trans. by R. D. Hicks, Cambridge: Harvard University Press.

MOST, G. W. (1989) "Cornutus and Stoic Allegoresis: A Preliminary Report", Aufstieg und Niedergang der Römischen Welt 36.3, ed. Wolfgang Haase, pp. 20142066.

Cantabrigiae.

ORIGENIS (1876). Contra Celsum, ed. Wilhelmus Selwyn, London;

PFEIFFER, Rudolf (1968). History of Classical Scholarship: From the Beginnings to the End of the Hellenistic Age, Oxford: Clarendon Press.

PLATON (1997). İon, çev. İhsan Bozkurt, İstanbul: MEB Yayınları.

PLATON (2000). Kratylos, çev. Cenap Karakaya, İstanbul: Sosyal Yayınları.

PLATON (2017). Devlet, çev. S. Eyüboğlu ve M. A. Cimcöz, İstanbul: Türkiye İş Bankası Kültür Yayınları.

PLATON (2019). Phaidros, çev. Ari Çokona, İstanbul: Türkiye İş Bankası Kültür Yayınları.

PLUTARCH (1976). On Stoic Self-Contradictions, Moralia Volume XIII: Part 2, trans. by Harold Cherniss, Cambridge: Harvard University Press.

RAMELLI, Ilaria (2011). "The Philosophical Stance of Allegory in Stoicism and its Reception in Platonism, Pagan and Christian: Origen in Dialogue with the Stoics and Plato", International Journal of the Classical Tradition, Vol. 18, No. 3, pp. 335-371.

SENECA, Lucius, Annaeus (1992). Ahlaki Mektuplar, çev. Türkân Uzel, Ankara: Türk Tarih Kurumu Basımevi.

SENECA, Lucius, Annaeus (2017). Bilgenin Sarsılmazlı̆̆ Üzerine, çev. C. Cengiz Çevik, İstanbul: Türkiye İş Bankası Kültür Yayınları. 
STRABO (1917). Geography, Volume I, trans. by H. L. Jones, Cambridge: Harvard University Press.

STRABO (1928). Geography, Volume V, trans. by H. L. Jones, Cambridge: Harvard University Press.

TATE, J. (1930). "Plato and Allegorical Interpretation (Continued)", The Classical Quarterly, Vol. 24, No. 1, pp. 1-10.

VAN SIJL, Clara (2010). Stoic Philosophy and the Exegesis of Myth. (Yayımlanmamış Doktora Tezi). Utrecht University, Netherlands.

YILDIRIM, Fatma Berna (2018). "Yorum Tarihinden Öğretici Bir Hata: Kitab1 Mukaddes Yorumculuğunda 'Tanrı'nın İsmi' Meselesi, Monograf, 2018/10, ss. 166199.

ZELLER, Eduard (1870). The Stoics, Epicureans and Sceptics, trans. by O. Reichel, London: Longmans, Green, and Co. 